\title{
THE EFFECT OF PROFITABILITY, LIQUIDITY, AND COMPANY SIZE ON CORPORATE SOCIAL RESPONSIBILITY DISCLOSURE
}

\author{
Oleh: \\ Shabira Nurulizzah Sahida \\ Puji Lestari \\ Warsidi \\ Accounting, Faculty of Economics and Business, Universitas Jenderal Soedirman, Indonesia \\ email: shabiraizza@gmail.com
}

\begin{abstract}
ABSTRAK
Penelitian ini bertujuan untuk mengetahui ada atau tidaknya pengaruh profitabilitas, likuiditas, dan ukuran perusahaan terhadap pengungkapan tanggung jawab sosial perusahaan.

Unit analisis penelitian ini adalah perusahan industry dasar dan kimia yang terdaftar di Bursa Efek Indonesia (BEI) periode 2016-2018, dengan populasi 62 perusahaan. Berdasarkan metode purposive sampling, diperoleh ukuran sampel sebanyak 26 perusahaan. Periode pengamatan selama 3 tahun, Hasil penelitian ini menunjukkan bahwa dan likuiditas berpengaruh negatif terhadap pengungkapan tanggung jawab sosial perusahaan. Ukuran perusahaan berpengaruh positif dan signifikan terhadap pengungkapan tanggung jawab sosial perusahaan.
\end{abstract}

Kata kunci: Pengungkapan tanggung jawab sosial perusahaan, profitabilitas, likuiditas, ukuran perusahaan

\begin{abstract}
ABSTRAK
This study aims to determine whether or not the influence of profitability, liquidity, and company size on corporate social responsibility disclosure.

The unit of analysis of this research is the basic and chemical industry companies listed on the Indonesian Stock Exchange (BEI) period of 2016-2018, with a population of 62 companies. Based on the purposive sampling method, a sample size of 26 companies was obtained. The observation period was 3 years, so the total number of observations was 78 data samples. The results of this study indicate that profitability and liquidity have no positive effect on corporate social responsibility disclosure. Company size has a positive effect on corporate social responsibility disclosure.
\end{abstract}

Keywords: Corporate social responsibility disclosure, profitability, liquidity, company size

\section{INTRODUCTION}

CSR disclosure according to Darwin (2007) is a disclosure in environment, social, and economy performance in annual report or separated report is to reflect the level of accountability, responsibility, and transparency corporate. Corporate social responsibility (CSR) means that a company must be responsible for every action that affects people, society, and their environment. In making decisions to implement social responsibility, companies 
do not only look at the economic impacts, such as the level of profits they will get. But companies must consider and take into account the social or environmental impacts arising from that decision, both in the short and long term. In every program implemented by the company it is hoped that it can provide useful benefits for both a few and most people. The goal is that companies, communities and the environment can coexist peacefully.

The development of CSR in Indonesia still requires a lot of attention because there are still many companies that have not implemented the CSR concept in their corporate activities. In the business world, which is engaged in the utilization of natural resources, either directly or indirectly, certainly has an impact on the surrounding environment. The impact on the environment can be felt by the surrounding community. Often companies in Indonesia that are engaged in the utilization of natural resources claim that they have carried out social obligations to the environment around the company. This needs to be considered because there have been several cases such as increased pollution and waste, road damage, poor air quality, excessive exploitation of natural resources, misuse of investment and others. The examples of cases of environmental damage are waste that pollutes the Citarum River Basin. The Ministry of Industry noted, in 2018, the textile industry is the dominant sector located in the Citarum River Basin with a population percentage reaching $70.9 \%$, followed by the food and beverage industry $(5.8 \%)$, metals $(4.9 \%)$, chemistry $(4.4 \%)$ and paper (3.6\%) (detikFinance, 08/25/2019). The industrial waste pollution caused by PT. Indah Kiat Pulp and Paper (IKPP) operating in Siak Regency, Riau such as air pollution and chemical waste discharged into the river flow have an impact on the air that is inhaled and water that is also used by the community.

The legal basis for corporate social responsibility is very strong. According to Law No. 40 of 2007 concerning Limited Liability Companies, requires companies whose business fields are in or related to the field of natural resources to carry out social and environmental responsibility. If the obligation (CSR) is not carried out, the company will worn to sanctions in accordance with statutory regulations. Article 74 paragraph 1 states that a company that carries out business activities in the fields and/or related to natural resources must carry out social and environmental responsibility. Other regulations relate to CSR are Government Regulation of the Republic of Indonesia Number 47 Year 2012 Concerning Social and Environmental Responsibility of Limited Liability Companies Article 3, paragraph (1) Social and environmental responsibility as referred 
to in Article 2 becomes an obligation for companies that execute their business activities in the field and / or relating to natural resources based on the Law, paragraph (2) The obligations referred to in paragraph (1) are execute both inside and outside the company's environment.

\section{LITERATURE REVIEW AND HYPOTHESIS DEVELOPMENT}

\section{Stakeholder Theory}

According to Freeman (1984), stakeholders as any group or individual who can affect or is affected by the achievement of the organisation's objectives. Stakeholder theory is a theory that illustrates that company not only operates for its own sake but can provide advantage for stakeholders.

The stakeholder theory embraces that business organizations must play an active role in society in which they operate. Wearing (2005) provides that stakeholder theory stresses the importance of all parties, who are affected, either directly or indirectly by a firm's operation. One of the companies to increase the value and benefits in the eyes of stakeholders is to carry out company activities related to social activities or corporate social responsibility.

\section{Legitimacy Theory}

Legitimacy theory comes from the concept of defined organizational legitimacy by Dowling and Pfeffer (1975) as condition or current status the company's value system is congruent with the social value system. Deegan and Unerman (2011) assert that the legitimacy theory relies upon the notion that there is a "social contract" between an organization and the society in which it operates. Therefore, corporation try to legitimize their corporate actions by engaging in CSR reporting to get the approval from society (societal approach) and thus, ensuring their continuing existence. The legitimacy theory also focuses the company on its interactions with the community, so that an organization is able to create a harmony between the morals inherent in its activities the norms of behavior that apply in the community. With the company's need to develop a CSR program, the company expect to contribute to the surrounding community so that community can accept the company's presence well and not to question the existence of the company.

\section{Corporate Social Responsibility Definition of CSR}

Corporate social responsibility can be defined as a company's commitment to realize and contribute to a sustainable economy through the company works and interacts positively with employees, families and communities around the company this aims to improve the quality of life together (WBCSD, 1998). 


\section{CSR Disclosure}

CSR disclosure according to Darwin (2007) is a disclosure in environment, social, and economy performance in annual report or separated report is to reflect the level of accountability, responsibility, and transparency corporate. CSR disclosure report has a function to create a good and effective communication between corporate and stakeholders about how corporate had integrated CSR in every aspect of their operational activities. If disclosure is related to information disclosure in the form of data, then disclosure will provide information to interested parties-stakeholders. Regarding to financial statements, company has responsibility to provide a description of how the company runs in a period. Therefore, the company must provide a complete, clear, and accurate picture of the activities actually carried out by the company.

\section{Profitability}

Profitability is the company's success in generating profits in a period (Kasmir, 2013). Company's profitability can describe the final results after the company carries out its decisions and policies in achieving its goals. Profitability is one of the factors considered in assessing whether a company is healthy or not other than capital, asset quality, management, and liquidity factors. Company profitability is an indicator of good company management so that management will tend to disclose more information when there is an increase in company profitability (Luciana, 2011).

\section{Liquidity}

Liquidity is the company's success in fulfilling all of its obligations, this obligation in the form of short-term and long-term obligations that are due in a period (Hani 2015: 121). Liquidity reflects the availability of company funds that are used to fulfill all obligations at maturity. Companies that are able to meet their financial obligations on time means that the firm is in a liquid state, and the firm be able to meet financial obligations on time if the firm has a payment or current asset that is greater than the current debt or short-term debt.

\section{Company size}

Company size is the level of identification of determining large or small in a company. Company size is divided into three categories, namely large, medium, and small companies (Suwito and Herawaty, 2005) Large companies will more often conduct the social responsibility disclosure than small companies, because this can be a means attracting investors and increasing community confidence. The impact that will be caused by the large company is greater than smaller companies. 
Effect of profitability on CSR disclosure

Stakeholder theory state that the higher the level of profitability the company produces, the greater the CSR disclosure tends to be because it is evidence of accountability to stakeholders. Companies that have good financial performance such as profitability will be more attractive to investors. In the theory of legitimacy, if the level of profitability of the company is good, the wider the level of corporate social responsibility disclosure, the company will get support for the achievement of company goals and legitimacy from the community.

Research conducted by Fitri (2017) state that profitability has a significant effect on CSR disclosure. Swandan and Sadikin (2016) state that the profitability has influence on CSR disclosure indicates that while a company wants to implement a CSR program, it needs sufficient funding sources.

H1: Profitability has a positive effect on Corporate Social Responsibility disclosure.

\section{Effect of liquidity on CSR disclosure}

Liquidity shows the ability of the company to comply its short-term obligations using the current assets available. Based on legitimacy theory that financial strength is indicated by a high liquidity ratio, so a company will tend to provide wider social responsibility disclosure information (Aini, 2015).
Companies with low levels of liquidity will focus more on improving their economic performance and giving low attention to the environment (Elijido-Ten 2004 in Aini, 2015).

H2: Liquidity has a positive effect on Corporate Social Responsibility disclosure.

\section{Effect of company size on CSR disclosure}

The company size is a scale used in decide a large or small company. In legitimacy theory, a company with a large size in carrying out operating activities that can have an impact on society and the environment, these companies will be required to provide information about corporate social responsibility. The bigger the company, the more widely the company will be required to disclose of CSR because the company will get positive value in the eyes of the community and legitimacy from the community.

Research conducted by of Wardhani and Muid (2017) state that company size has a positive effect on CSR. As the research of Fitria (2019) state that the company size has a significant effect on the corporate social responsibility disclosure. Based on description above, hypotheses in this study can be concluded:

H3: Company size has a positive effect on Corporate Social Responsibility disclosure. 


\section{RESEARCH METHODS}

\section{Research Design}

Type of this research is quantitative research that using secondary data. The population of this research are 62 basic industry and chemicals companies that listed on the Indonesia Stock Exchange (IDX) in 20162018. A sampling method using purposive sampling and the sample of this research is 26 basic industry and chemicals companies .This research uses multiple linear regression analysis as a data analysis technique. Data processing using SPSS.

\section{Conceptual definition and operational variables}

\section{Dependent Variable (Y)}

The dependent variable in this research is the corporate social responsibility disclosure. CSR disclosures are measured through Corporate Social Disclosure Index (CSDI). In this study uses the GRI (Global Reporting Index) of the Global Reporting Initiative which is an independent institution that develops and promotes sustainability reporting guidelines by giving direction to companies in publishing sustainable reports about their CSR. GRI Guidelines 4 is used in this study as a guide to information related to indicators in measuring CSDI companies to be researched. CSDI calculations are done using the scoring method, i.e. an item that is disclosed nis given a value of 1 and when not disclosed gets a value of 0 .
The CSDI calculation formula is as follows (Haniffa, et al, 2005) :

$$
C S D I_{j}=\frac{\sum \mathrm{Xij}}{91} \times 100 \%
$$

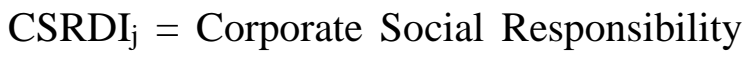
Disclosure Index company $\mathbf{J}$ $\sum \mathrm{Xij}=\mathrm{Xi}$ is worth 1 if item $\mathrm{i}$ expressed and $\mathrm{Xi}$ is worth 0 if item $\mathrm{i}$ not disclosed

\section{Independent Variables $(\mathrm{X})$}

\section{Profitability $\left(\mathbf{X}_{1}\right)$}

ROA is a ratio that describes the company's ability to generate profits. The greater the ratio is better because the management of the company can generate the best possible profit on the assets owned. To calculate the profitability can be calculated using the following formula according to Brigham dan Houston (2011):

$$
R O A=\frac{\text { Net Income }}{\text { Total Assets }} \times 100 \%
$$

\section{Liquidity $\left(\mathbf{X}_{2}\right)$}

The liquidity ratio is used to measures a company's ability to pay shortterm obligations. The higher the liquidity ratio, the better it will be for investors. Companies that are interested in investors are companies that have good financial performance such as a high liquidity ratio. To calculate the liquidity ratio can be calculated using the following formula according to Brigham dan Houston (2011): 
Current Ratio $=\frac{\text { Current Assets }}{\text { Current Liabilities }}: 100 \%$

\section{Company size $\left(\mathbf{X}_{3}\right)$}

Company size is a way of identifying the size of a company. Company size variables can be measured using logarithmic values of company's total assets (Maulida et al, 2014). Therefore, in this study the logarithm of total assets is used to measure company size. This independent variable uses the Rupiah currency and is given the symbol SIZE.

$$
\text { SIZE }=\text { Ln Total Asset }
$$

\section{RESULT AND DISCUSSION}

\section{Research Overview}

Table 1. Sample Selection

\begin{tabular}{llc}
\hline No & \multicolumn{1}{c}{ Criteria } & Total \\
\hline 1. & $\begin{array}{l}\text { The basic industry and chemicals sector companies listed on } \\
\text { the Indonesia Stock Exchange in 2016-2018 }\end{array}$ & 62 \\
2. & $\begin{array}{l}\text { The basic industry and chemicals sector company that do not } \\
\text { publishes the annual report in a row in 2016-2018 }\end{array}$ & $(5)$ \\
3. & $\begin{array}{l}\text { The company that do not disclosure of social responsibility in } \\
\text { the annual report during the period 2016-2018 }\end{array}$ & $(2)$ \\
4. & Outlier data $\quad$ Total Sample is used & $\mathbf{2 6}$ \\
\hline
\end{tabular}

Source: Secondary data processed, 2020

Results of Analysis and Discussion

Descriptive statistic analysis
Descriptive statistical test results from the research sample can be seen in the table below.

Table 2. Result of Descriptive Statistic

\begin{tabular}{lccccc}
\hline & N & Minimum & Maximum & Mean & $\begin{array}{c}\text { Std. } \\
\text { Deviation }\end{array}$ \\
\hline Profitability & 78 & 4.12 & 5.65 & 4.9517 & 0.34897 \\
Liquidity & 78 & 0.05 & 0.17 & 0.1133 & 0.02293 \\
Company Size & 78 & 2.22 & 3.29 & 2.7602 & 0.22495 \\
CSRD & 78 & 2.57 & 4.92 & 3.7927 & 0.71943 \\
Valid N & 78 & & & & \\
(listwise) & & & & & \\
\hline
\end{tabular}

Source: SPSS output result proceed, 2020 


\section{Classic assumption test}

a. Normalizing data using SQRT and

\section{Outlier method}

\section{1) Normality Test}

This study used KolmogorovSmirnov Z (1-Sample KS).

Table 3. Normality Test Result

\begin{tabular}{lr}
\hline & Unstandardized Residual \\
\hline $\mathrm{N}$ & 78 \\
Test Statistic & 0.092 \\
Asymp. Sig. (2-tailed) & 0.167 \\
\hline
\end{tabular}

Source: SPSS output result proceed, 2020

2) Multicollinearity Test

From the test results obtained a significance value of $0.167>0.05$. Based on the normality test criteria, it can be concluded that the data is normally distributed.
To

detect

multicollinearity symptoms it is determined by the tolerance value and variance inflation factor (VIF) value. Data is said to be good if the value tolerance more than 0.10 and the value of VIF (Variance Inflation Factor) is less than 10 .

Table 4. Multicollinearity Test Result

\begin{tabular}{lll}
\hline & \multicolumn{2}{c}{ Collinearity Statistics } \\
Variable & Tolerance & VIF \\
\hline Profitability & 0.717 & 1.394 \\
Liquidity & 0.709 & 1.411 \\
Company size & 0.957 & 1.045 \\
\hline
\end{tabular}

Source: SPSS output result proceed, 2020

Table 4 shows that the profitability, liquidity, company size variables have a VIF value $\leq 10$ and a tolerance value $\geq 0.10$, so it can be concluded that there is no multicollinearity.
3) Heteroscedasticity Test

A heteroscedasticity test is used the Glejser method. Decision making in the Glejser method, if the significance value is > 0.05 , then there is no heteroscedasticity. 
Table 5. Heteroscedasticity Test Result

\begin{tabular}{lc}
\hline \multicolumn{1}{c}{ Variable } & Sig. \\
\hline Profitability & 0.870 \\
Liquidity & 0.609 \\
Company size & 0.207 \\
\hline
\end{tabular}

Source: SPSS output result proceed, 2020

Table 5 shows that the profitability, liquidity, company size variables have a significance value $>0.05$. So it can be concluded that there was no heteroscedasticity in this regression model.
The autocorrelation test aims to test whether there is a correlation between the previous periods (Janie, 2012). The autocorrelation test in this study will be carried out uses DurbinWatson test.

\section{4) Autocorrelation test}

Table 6. Autocorrelation Test Result

\begin{tabular}{|c|c|c|c|c|c|}
\hline Model & $\mathrm{R}$ & R Square & $\begin{array}{l}\text { Adjusted R } \\
\text { Square }\end{array}$ & $\begin{array}{l}\text { Std. Error of the } \\
\text { Estimate }\end{array}$ & $\begin{array}{l}\text { Durbin- } \\
\text { Watson }\end{array}$ \\
\hline 1 & $.545^{\mathrm{a}}$ & .297 & .268 & .61553 & .927 \\
\hline
\end{tabular}

Source: SPSS output result proceed, 2020

From the test results the Durbin Watson value is 0.927 . Based on the classification of DW values $\mathrm{a}=5 \%, \mathrm{k}=3$, and $\mathrm{n}$ $=78$, the results from the DW table are dL value of 1.5535 and dU value of 1.7129. From these results it is known that the Durbin Watson value of 0.927 is located between 0 and $\mathrm{dL}$, which means that there is positive autocorrelation in the regression model.

\section{b. Normalization of data with the transformation of the Cochrane Orcutt method}

After testing the classical assumptions of the dependent and independent variables that have been transformed by the SQRT method and 
outlier data, there is a test that does not pass, namely autocorrelation. Therefore, a Cochrane-Orcutt transformation was undertaken to solve the problem. This method reduces the amount of panel data from 78 to 77.

\section{1) Normality Test}

Table 7. Normality Test Result

\begin{tabular}{lr}
\hline & Unstandardized Residual \\
\hline $\mathrm{N}$ & 77 \\
Test Statistic & 0.081 \\
Asymp. Sig. (2-tailed) & 0.200 \\
\hline
\end{tabular}

Source: SPSS output result proceed, 2020

$\begin{array}{ll}\text { Based on test results } & 0.200>0.05 . \text { So, it can be } \\ \text { using data that had been } & \text { concluded that the data is } \\ \text { transformed by the Cochrane } & \text { normally distributed. }\end{array}$

Orcutt, a significance value of

2) Multicollinearity Test

Table 8. Multicollinearity Test Result

\begin{tabular}{lll}
\hline & \multicolumn{2}{c}{ Collinearity Statistics } \\
Variable & Tolerance & VIF \\
\hline Profitability & 0.760 & 1.316 \\
Liquidity & 0.752 & 1.330 \\
Company size & 0.988 & 1.012 \\
\hline
\end{tabular}

Source: SPSS output result proceed, 2020

From the test result obtained the profitability, liquidity, company size variables have a VIF value $\leq 10$ and a tolerance value $\geq 0.10$, so it can be concluded that there is no multicollinearity.

\section{3) Heteroscedasticity Test}

Table 9. Heteroscedasticity Test Result

\begin{tabular}{lc}
\hline \multicolumn{1}{c}{ Variable } & Sig. \\
\hline Profitability & 0.974 \\
Liquidity & 0.374 \\
Company size & 0.755 \\
\hline Source: SPSS output result proceed, 2020
\end{tabular}


From the test result obtained the profitability, liquidity, company size variables have a significance value $>0.05$. So it can be concluded that there was no heteroscedasticity in this regression model.

\section{4) Autocorrelation Test}

Table 10. Autocorrelation Test Result

\begin{tabular}{llrrrr}
\hline Model & R & R Square & $\begin{array}{c}\text { Adjusted R } \\
\text { Square }\end{array}$ & $\begin{array}{c}\text { Std. Error of the } \\
\text { Estimate }\end{array}$ & $\begin{array}{c}\text { Durbin- } \\
\text { Watson }\end{array}$ \\
\hline 1 & $.460^{\text {a }}$ & .212 & .179 & 0.51580 & 1.813 \\
\hline a. Predictors: (Constant), LAG_X3, LAG_X1, LAG_X2 & & \\
b. Dependent Variable: LAG_Y \\
Source. SPSS output result proceed, 2020
\end{tabular}

From the test result obtained the Durbin-Watson (DW) value is 1.813. This means that the DW value is between DU and 4-DU, which is $1.7129<1.813<2.2871$. So it can be concluded that the regression model is no autocorrelation.

\section{Multiple Linear Regression Analysis}

Multiple linear regression is used to figure out the effects arising from independent variables against dependent variables.

Tabel 11.

Multiple Linear Regression Analysis Result

\begin{tabular}{|c|c|c|c|c|c|c|}
\hline & \multicolumn{5}{|c|}{ Standardize } \\
\hline & & \multirow{2}{*}{\multicolumn{2}{|c|}{$\begin{array}{l}\text { Unstandardized } \\
\text { Coefficients }\end{array}$}} & \multirow{3}{*}{$\begin{array}{c}\text { d } \\
\text { Coefficients } \\
\text { Beta }\end{array}$} & \multirow[b]{3}{*}{$\mathrm{t}$} & \multirow[b]{3}{*}{ Sig. } \\
\hline & & & & & & \\
\hline & & B & Std. Error & & & \\
\hline \multirow[t]{4}{*}{1} & (Constant) & 0.317 & 0.794 & & 0.399 & 0.691 \\
\hline & LAG_X1 & -0.198 & 0.229 & -0.103 & -0.864 & 0.390 \\
\hline & LAG_X2 & 2.109 & 3.657 & 0.069 & 0.577 & 0.566 \\
\hline & LAG_X3 & 1.400 & 0.330 & 0.444 & 4.246 & 0.000 \\
\hline
\end{tabular}

a. Dependent Variable: LAG_Y

Source: SPSS output result proceed, 2020

The results of multiple linear regression equation are as follows:

$$
\text { CSRD }=0.317-0.198 X_{1}+2.109 X_{2}+1.400 X_{3}
$$


Volume 2, Nomor 2, Februari 2021, pp 187-204. Copyright @ 2019 JAFTA, Program Studi Magister Akuntansi, Fakultas Ekonomi, Universitas Kristen Maranatha. ISSN: 2654-4636 | E-ISSN: 2656-758X https://journal.maranatha.edu/index.php/jafta

\section{Goodness of Fit Test}

The $\mathrm{F}$ test performed to show the influence of the independent variables on the dependent variable in the regression model.

Table 12. F Test Result

\begin{tabular}{|c|c|c|c|c|c|}
\hline Model & Sum of Squares & df & Mean Square & $\mathrm{F}$ & Sig. \\
\hline 1 Regression & 5.215 & 3 & 1.738 & 6.534 & $0.001^{b}$ \\
\hline Residual & 19.422 & 73 & 0.266 & & \\
\hline Total & 24.636 & 76 & & & \\
\hline
\end{tabular}

Source: SPSS output result proceed, 2020

means that it is above the significance level

In table 14 the F value Sig. of 0.001 , which means less than 0.05 . The regression model used in the study fell into the fit category. So, the variables of profitability, liquidity and company size together have a simultaneous effect on corporate social responsibility disclosure.

\section{Hypothesis Test}

Based on the summary of multiple linear regression analysis in Table 11, profitability has a no significant effect with a significance value of 0.390 which means that it is above the significance level of 0.05 . Profitability variable has negative value of 0.198. This shows that the profitability variable has a negative and no significant effect the corporate sosial responsibility disclosure. Thus, the first hypothesis which states that profitability has a positive effect on corporate sosial responsibility disclosure is rejected.

Liquidity has a no significant effect with a significance value of 0.566 which of 0.05 . Liquidity variable (X2) has positive value of 2.109. This shows that the liquidity variable has a positive and no significant effect the corporate sosial responsibility disclosure. Thus, the second hypothesis which states that liquidity has a positive effect on corporate sosial responsibility disclosure is rejected.

Company size has a significance value of 0.000 which means below the significance level of 0.05 . Company size variable has positive value of 1.400 . This shows that the company size variable has a positive and significant effect the corporate sosial responsibility disclosure. Thus, the third hypothesis which states that company size has a positive effect on corporate sosial responsibility disclosure is accepted.

\section{Discussion}

\section{Effect of profitability on CSR disclosure}

The results of this study do not support either the legitimacy theory or the stakeholder theory. In the stakeholder theory 
states that the higher the level of profitability the company produces, the greater the CSR disclosure tends to be because it is evidence of accountability to stakeholders. While the legitimacy theory explains that if the level of profitability of the company is good, the greater the level of disclosure of corporate social responsibility to get positive value and legitimacy from the community, which will increase the company's profits in the future. According to Donovan and Gibson (2000) in Sembiring (2005), when companies with a high level of profitability, companies consider it unnecessary to report things that can interrupt with information concerning the company's financial success. Conversely, when profitability is low, they expect to report users to read the good news of social and environmental performance.

The results of this test show that profitability has no effect on corporate social responsibility disclosure. Companies with a high level of profitability, which means they have sufficient funds to be allocated to social and environmental activities, do not necessarily allocate these funds to social and environmental activities so that the level of disclosure of social responsibility is low (Purwanto, 2011). Because with social and environmental disclosure, companies have to pay additional costs to disclose social information.

The result of this study is consistent with research conducted by Dutcyh and
Krasodomska (2017) and Wardhani and Muid (2017) which states that there is no effect of the level of profitability on the disclosure of CSR information by companies. Thus, the existence of company profitability has not been able to influence the extent of disclosure of corporate social responsibility.

\section{Effect of liquidity on CSR disclosure}

The results of this study indicate that the greater the level of company liquidity does not necessarily affect the broader corporate social responsibility disclosure information. This study are not in accordance with the legitimacy theory which says that financial strength is indicated by a high liquidity ratio, so a company will tend to provide wider social responsibility disclosure information (Aini, 2015). Companies tend not to carry out social disclosures because by having good financial performance, companies assume that CSR disclosure has no effect on attracting investors (Sekarwigati and Effendi, 2019). In addition, CSR is an obligation for companies that are useful for maintaining the survival of the company, so that the higher or lower the company's liquidity does not affect the level of CSR disclosure.

The research show that liquidity has no effect on corporate social responsibility disclosure. This means that high or low 
liquidity does not affect the level of corporate social responsibility disclosure. The higher the level of liquidity, the company assumes that it is only necessary to disclose of corporate social responsibility in the annual report because it is considered to have no influence on investors (Kesuma, 2017). The result of this study is consistent with research conducted by Saputra et al. (2017) and Aini (2015) state liquidity had no effect on corporate social responsibility disclosure.

\section{Effect of company size on CSR disclosure}

The large and small of the company do not guarantee that companies make extensive disclosures. The large or small size of the company will affect the company in making corporate social responsibility disclosures. This research is in accordance with the legitimacy theory which states that companies with large sizes in carrying out operational activities that can have an impact on society and the environment, these companies will be required to provide information about corporate social responsibility. Large companies tend to be highlighted the most by the public so that companies will disclose more detailed information, one of which is information about the social responsibility that must be carried out by companies because large companies are the center of attention for both investors and the wider community so that by disclosing CSR the company will be able to appeal investors to invest in companies (Fitria, 2017).

The results of this test indicate that company size has positive and significant effect on corporate social responsibility disclosure. The results of this study are consistent with Wardhani and Muid (2017) which states that the larger the size of company, the wider CSR information disclosure is carried out by the company. A large company will attract the attention of the public so that the company is required to have a good performance. The way to show good performance is by paying more attention to social-environmental conditions, namely by making wider disclosures of corporate social responsibility so that the company has a good image and trust from the community.

\section{CONCLUSION}

1. Profitability has no positive effect on the corporate sosial responsibility disclosure in the basic industry and chemicals companies in 2016-2018.

2. Liquidity has no positive effect on the corporate sosial responsibility disclosure in the basic industry and chemicals companies in 2016-2018.

3. Company size has a positive effect on the corporate sosial responsibility disclosure in the basic industry and chemicals companies in 2016-2018. 


\section{Implication}

1. Theoretical Implication

The results of this study indicate that profitability has no positive effect on corporate sosial responsibility disclosure. Liquidity has no positive effect on corporate sosial responsibility disclosure. Company size has a positive effect on corporate sosial responsibility disclosure. The company's CSR programs are able to help the community in improving their economic lives. Theoretically, the results of this study are expected to provide benefits and add references for future similar research on corporate responsibility disclosure in Indonesia.

2. Practical Implication

For investors, this can be a consideration and evaluation material so that they are not mistaken in choosing to invest in a company. For companies, CSR disclosure can be used as a tool for investment and the sustainability of the company in the future, so that companies carrying out activities and CSR disclosures will certainly maintain and form a good image to stakeholders.

\section{Limitation}

1. This research was only conducted at basic industry and chemicals companies. So for further research is supposed to expand the object of research.

2. The variable used is less in describing the effect on corporate sosial responsibility disclosure. So for further research, can replace or add to other variables.

3. The sample taken in this study was only three years of observation.

\section{REFERENCES}

Aini, A. K. (2015). Pengaruh Karakteristik Perusahaan Terhadap Pengungkapan Tanggung Jawab Sosial Perusahaan (CSR) Pada Perusahaan Yang Terdaftar Di Indeks LQ45 Bursa Efek Indonesia (BEI). Economic and Business Faculty of Mulawarman University, 12(1).

Brigham, EF, JF Houston. 2011. Manajemen Keuangan, Penerbit Erlangga

Darwin. (2007). Pentingnya Laporan Keberlanjutan, Akuntan Indonesia, 3 (1), 14-12-2007

Deegan, C., and Unerman, J., (2011). Finanical accounting theory, McGraw-Hill, Sydney.

Dowling, J. and Pfeffer, J. (1975). Organizational Legitimacy: Social values and Organizational Behavior. Pacific Sociological Review. Vol.18 No.1 Page 122-136. 
Dyduch, J., \& Krasodomska, J. (2017). Determinants of Corporate Social Responsibility Disclosure: An Empirical Study of Polish Listed Companies. Sustainability, 9(11), 124.

Fitria, E. (2017). Faktor-Faktor Yang Memengaruhi Pengungkapan Corporate Social Responsibility (Thesis). Muhammadiyah Yogyakarta University.

Freeman, R. E., (1984). Strategic Management: A Stakeholder Approach. Pitman, Boston

Ghozali, I. (2006). Aplikasi Analisis Multivariate dengan Program SPSS. Semarang: Badan Penerbit Universitas Diponegoro.

Hani, S. (2015). Teknik Analisa Laporan Keuangan. Medan: UMSU Press.

Haniffa,RM. T.E. Cooke. 2005. The impact of culture and governance on corporate social reporting. Journal of Accounting and Public Policy 24 (2005) 391-430.

Kasmir. (2014). Analisis Laporan Keuangan. Edisi Satu. Cetakan Ketujuh. Jakarta: Rajagrafindo Persada

Kesuma, R. (2017). Pengaruh Profitabilitas, Likuiditas, Growth, Media Exposure dan Kinerja Lingkungan Terhadap Pengungkapan Corporate Social Responsibility (Thesis). Economic and Business Faculty.
Muhammadiyah

Yogyakarta

University.

Luciana, S., Nurul, H., dan Vidiana. (2011).

"Faktor-Faktor Yang Mempengaruhi PengungkapanTanggung Jawab Sosial Dan Dampaknya Terhadap Kinerja Keuangan Dan Ukuran Perusahaan. Fokus Ekonomi”. Volume 10. No 1

Maulida, et.all. (2014). Analisis FaktorFaktor yang Mempengaruhi Pengungkapan Islamic Social Reporting (ISR). Simposium Nasional Akuntansi. Universitas Negeri Semarang

Purwanto, A. (2011). Pengaruh Tipe Industri, Ukuran Perusahaan, Profitabilitas, Terhadap Corporate Social Responsibility. Jurnal Akuntansi \& Auditing, 8(1), 12-29.

Saputra, M., Nadirsyah, Iranda, F. N., \& Hamdani. (2018). The Influence of Corporate Profitability and Corporate Liquidity on Corporate Social Responsibility Disclosure. Faculty of Economic and Business, Syiah Kuala University.

Sekarwigati, M., \& Effendi, B. (2019). Pengaruh Ukuran Perusahaan, Profitabilitas dan Likuiditas Terhadap Corporate Social Responsibility Disclosure. Jurnal Akuntansi dan Keuangan, 1(1), 1633. 
Sembiring, E. R. (2006). Karakteristik

Perusahaan dan Pengungkapan

Tanggung Jawab Sosial: Study

Empiris pada Perusahaan yang

Tercatat di Bursa Efek Jakarta.

Jurnal Maksi, 6(1), 69-85.

Septiana, F., \& Fitria, A. (2014). Pengaruh

Karakteristik Perusahaan Terhadap

Corporate Social Responsibility

Pada Perusahaan Manufaktur.

Journal of Accounting and https://www.idx.co.id/

Research, 3(7).

Simamora, B. T. (2017). Pengaruh

Profitabilitas dan Ukuran

Perusahaan Terhadap Pengungkapan

Corporate Social Responsibility

(Thesis). Universitas Pendidikan

Indonesia.

Suwito, E., and Herawaty, A. (2005).

Analisis Pengaruh Karakteristik

Perusahaan terhadap Tindakan

Swandari, F., \& Sadikin, A. (2016). The

Effect of Ownership Sctructure,

Profitability, Leverage, and Firm

Size on Corporate Social

Responsibility. Binus Business

Review, 7(3).

Wardhani, R. A., \& Muid, D. (2017).

Pengaruh Agresivitas Pajak, Ukuran

Perusahaan dan Profitabilitas

Terhadap Corporate Social

Responsibility. Diponegoro Journal

of Accounting, 8(3).
Wearing, R., (2005). Cases in corporate governance. London. SAGE Publications

World Business Council of Sustainable Development. (1998, September). WBCSD - Corporate Social Responsibility. Retrieved November 07, 2019, from World Business Council for Sustainable Development (WBCSD)

\section{he//WwW.idx.coid/}


JAFTA - Vol 2 Nomor 2, Februari (2021) 